\title{
장애아 부모의 언어치료실 선택속성 분석 \\ Analysis on the Relative Importance and Priority in Speech Therapy \\ Center of Parents of Children with Disabilities
}

\author{
김선 ${ }^{*}$ 홍경훈 ${ }^{* *}$ \\ 인천발달센터*, 나사렛대학교 언어치료학과**
}

Sun Kim(kimsun1977@hanmail.net) ${ }^{*}$,Gyung Hun Hong(ghun@kornu.ac.kr)**

\section{요약}

본 연구의 목적은 언어장애아동의 부모들이 언어치료실을 선택할 때 중요하게 고려하는 선택속성이 무엇 인가를 탐색하는데 있었다. 자료는 예비조사, 계층분석용(AHP) 설문지 구성을 위한 1차 조사 그리고 계층 분석용 2 차 조사의 3 단계 절차를 통해 수집되었다. 총 대상자의 수는 252 명이었다. 연구결과는 다음과 같았 다. 첫째, 부모들이 언어치료실을 선택할 때 가장 중요하게 생각하는 상위속성들 간의 우선순위는 '치료사 속성', ‘프로그램 속성', ‘물리적 속성' 순이었으며, 하위속성들 중에서는 ‘치료사의 학력과 전공', ‘유대관계 형성능력', '경력 및 자격증 급수, '친절성과 신뢰성' 그리고 '부모상담’ 순으로 높은 우선순위를 나타냈다. 둘째, 연령집단별로 학령전기와 학령기로 나누어 분석한 결과, 6 세 이하의 학령전기 아동의 부모들은 '치료 사의 경력 및 자격증급수', ‘부모상담', ‘교재교구의 다양성’을 각 상위속성별로 가장 중요한 하위속성으로 선택한 반면, 학령기 아동의 부모들은 '치료사의 학력 및 전공', '언어치료 비용', '거리·교통 - 주차'를 각각 최우선 순위로 선택하였다. 본 연구는 언어장애아동 부모들의 언어치료실 선택속성들을 분석하여 향후 효 율적인 언어치료 프로그램을 계획하기 위한 기초 자료를 제공했다는데 의의가 있다.

중심어 : | 장애아 부모 | 언어치료실 | 선택속성 |

\section{Abstract}

The purpose of this study is to explore the selection attributes for parents of children with language disability when choosing a clinic. The data collection was carried out in 3 steps: the preliminary survey, first open survey and second survey in AHP(Analytic Hierarchy Process). The subjects of were 252 in total. The results were as follows: First, The order of priority attributes in superior categories for parents of children with language disability when selecting a clinic were 'therapist-related attributes', 'program-related attributes' and 'physical-related attributes' in turn. The top 5 priority attributes in subcategories were 'therapist's academic background and major', 'ability to make a rapport', 'clinical experience and qualification of therapist', 'kindness and confidence' and 'counseling program for parents'. Second, The parents of preschoolers age 6 and younger chose 'clinical experience and qualification of therapist', 'counseling program for parents' and 'learning materials' for the most priority attributes, whereas the parents of students age from 7 to 12 , considered 'therapist's academic background and major', 'clinical fee' and 'distance - transport - parking' more importantly to select a clinic. The results of this study provided preliminary data for successful planning of speech and language therapy.

keyword : | Parents of Children with Disability | Speech-language Clinic Center I Selection Attribution |

* 이 논문은 제 1 저자의 석사학위논문 자료를 수정·보완한 것입니다.

접수번호 : \#121116-001

심사완료일 : 2013년 01월 14일

접수일자 : 2012년 11월 16일

교신저자 : 홍경훈, e-mail : ghun@kornu.ac.kr 


\section{I. 서 론}

최근 치료비지원 바우처사업 실태파악 분석을 통한 연구보고서에 따르면[1], 우리나라 장애아동재활치료서 비스 이용자들 중 약 $40 \%$ 가 언어치료를 받고 있으며, 20여 가지의 장애아동재활치료서비스 중 가장 높은 비 율을 차지하는 것으로 나타났다. 또한 현재 받고 있는 재활서비스와 관계없이 가장 받고 싶은 재활치료로 응 답자의 약 $30 \%$ 가 언어치료라고 응답하였다. 언어치료 요구가 높은 이유는 의사소통능력에 결함이 있는 언어 장애 아동들은 타인과 사회적 관계를 형성하고 학습하 는데 많은 어려움이 있으며, 언어치료를 통해 자연스러 운 환경에서 개인의 의사소통 능력을 향상시키고 그를 통하여 삶의 질을 향상시킬 수 있기 때문이다[2].

많은 장애아동들의 경우에 상당한 연령에 도달했음 에도 본인들이 참여하는 활동이나 기관에 대해 스스로 의사 결정을 내리는 것이 쉽지 않기 때문에 부모나 보 호자가 관련 정보들을 탐색하고 분석하여 결정할 때가 많다[3]. 따라서 장애아동의 재활치료관련 요구를 분석 하기 위해서는 부모의 요구를 고려하지 않을 수 없다. 그러므로 언어치료가 효율적으로 이루어지기 위해서는 장애아 부모의 요구를 정확히 파악하여 치료교육에 투 입해야 하는 것이 중요하다. 장애아 부모의 요구를 고 려하는 것은 장애아 부모가 서비스 지원에 대한 적절한 계획을 세우는데 도움을 줄 수 있으며[4], 장애아 부모 의 요구를 진단하는 것은 장애아 부모를 위한 부족한 지원 서비스를 규명하고 도울 수 있다[5].

속성이란 상품이 지닌 유·무형의 특징을 가리키는 의 미로 사용되는데[6], 언어치료실을 선택하는데 있어 장 애아 부모들이 공통적으로 나타나내는 일정한 특징을 선택속성이라고 할 수 있다. 선택속성은 최종적인 의사 결정에 영향을 미치는 중요한 기준 중의 하나이기 때문 에 가장 중요한 핵심요인을 이해하기 위해 자주 활용된 다[7-9]. 구체적으로 장애아 부모가 언어치료실을 선택 할 때 기준이 되는 속성이 무엇인가를 탐색하는 과정은 제공하는 기관마다 다른 인력구성과 환경조건에서 공 급자 중심이 아닌 수요자 측면을 심도 있게 이해하는 과정이다. 따라서 장애아 부모의 언어치료실 선택속성
을 이해하는 과정은 치료실을 기획하고 계획하는데 필 요한 정보를 제공하며, 언어치료사에게는 언어치료를 할 때 부모의 요구를 파악할 수 있는 중요한 정보를 제 공할 수 있다.

장애아동의 연령은 재활치료서비스나 재활치료기관 을 선택할 때 고려해야 할 중요한 요인 중 하나이다 [10]. 특수교육에서도 일반적으로 대상아동의 연령에 따라서 장애 유아를 위한 유아특수교육과 장애 영아를 위한 조기개입으로 분류한다[11]. 이렇게 대상자의 연 령에 따라 구분되는 것은 이들 두 집단이 지니고 있는 교육적 요구와 그에 따른 서비스의 형태가 달라질 수 있기 때문이다[12]. 김수진[10]의 연구에서 연령대별로 언어치료 요구 및 이용 현황을 분석한 결과, 모든 연령 대에서 재활치료 중 언어치료에 대한 요구가 가장 높게 나타났으며, 3세 이하의 $46 \%, 477$ 세 이하의 $56.6 \%$, 8 13 세의 $37.2 \%$ 그리고, 14 세 이상의 $27.5 \%$ 가 언어치 료에 대한 우선 요구를 나타냈다. 언어치료 이용 현황 분석결과, 학령전기인 $4^{\sim} 7$ 세에는 재활치료 대상자 중 약 55\%, 8 13세에는 37\%, 그리고 중학교 이상에서는 $27 \%$ 로 이용률이 점점 떨어지는 것으로 나타났다. 이러 한 결과는 [10][11]의 연구에서 나타난 바와 같이 장애 아의 연령집단별로 언어치료에 대한 요구가 다를 수 있 음을 시사한다.

현재 국내에서 병원, 특수학교, 복지관, 장애전담 어 린이집과 같은 기관에서 제공하는 언어치료에 대한 실 태와 만족도에 관한 연구는 실시된 바 있으나[13-26], 장애아 부모의 언어치료실에 대한 요구를 우선순위로 분석한 연구는 실시된 바 없다. 장애아 부모의 언어치 료 관련 속성들에 대한 우선순위를 분석하여 이를 임상 현장에 반영함으로써, 이들의 요구를 충족시키는 것은 언어치료의 질적인 향상을 위해 필수적이다.

따라서 본 연구는 언어치료를 받고 있는 장애아 부모 가 언어치료실을 선택할 때 중요하게 고려하는 선택속 성들과 속성들 간의 상대적 우선순위를 전반적 그리고 연령집단별로 분석하여 언어치료의 효율적인 운영방안 을 모색하고자 하였다.

본 연구의 구체적인 연구문제는 다음과 같았다. 
첫째, 장애아 부모가 언어치료실을 선택할 때 중요하 게 생각하는 선택속성은 무엇이며, 속성들의 우 선순위는 어떠한가?

둘째, 장애아 부모의 언어치료실 선택속성 우선순위 는 아동의 연령집단별로 어떠한 차이가 있는가?

\section{II. 연구방법}

\section{1. 연구대상}

연구대상은 서울, 인천, 경기지역에 있는 총 6 개의 아 동발달센터에서 언어치료를 받고 있는 아동의 부모들 이었다. 예비조사는 아동의 연령을 0 3세, 4 6세, 7 9세, 10 12세의 집단으로 나누어 각 집단별로 5명씩, 장애아 부모 총 20명을 대상으로 조사를 실시하였다. 이후 실시된 1 차 본 조사를 위한 개방형 설문지의 대상 자는 연령집단별로 15 명씩으로 총 60 명이었으며[표 1], 이후 2 차 본 조사인 계층분석용 설문지의 대상자는 연 령집단별로 48명씩, 총 192명이었다[표 2]. 각 조사 단 계별로 이전 단계에 포함된 대상자는 다음 조사에 포함 하지 않았다.

\section{표 1, 1 차 본 조사 대상의 배경정보(총 60 명)}

\begin{tabular}{|c|c|c|c|}
\hline 구분 & 항목 & 빈도 & 비율 \\
\hline \multirow{3}{*}{$\begin{array}{l}\text { 부모 } \\
\text { 연령 }\end{array}$} & 20대 & 10 & 16.7 \\
\hline & 30대 & 27 & 45 \\
\hline & 40대 & 23 & 38.8 \\
\hline \multirow{2}{*}{$\begin{array}{l}\text { 부모 } \\
\text { 학력 }\end{array}$} & 고등학교 & 20 & 33.3 \\
\hline & 대학교 & 40 & 66.7 \\
\hline \multirow{5}{*}{$\begin{array}{c}\text { 가족 } \\
\text { 월평균 소득 }\end{array}$} & 200만원 미만 & 1 & 1.7 \\
\hline & 200만원 300만원 미만 & 3 & 5 \\
\hline & 300만원 400만원 미만 & 14 & 23.3 \\
\hline & 400만원 500만원 미만 & 24 & 40 \\
\hline & 500 만원 이상 & 18 & 30 \\
\hline \multirow{4}{*}{$\begin{array}{l}\text { 아동 } \\
\text { 연령 }\end{array}$} & 0 3세 & 15 & 25 \\
\hline & 4 6세 & 15 & 25 \\
\hline & 7 9세 & 15 & 25 \\
\hline & 10 12세 & 15 & 25 \\
\hline \multirow{2}{*}{$\begin{array}{l}\text { 아동 } \\
\text { 성별 }\end{array}$} & 여자 & 20 & 33.3 \\
\hline & 남자 & 40 & 66.7 \\
\hline
\end{tabular}

표 2. 2차 본 조사 대상의 배경정보(총 192명)

\begin{tabular}{|c|c|c|c|}
\hline 구분 & 항목 & 빈도 & 비율 \\
\hline \multirow{3}{*}{$\begin{array}{l}\text { 부모 } \\
\text { 연령 }\end{array}$} & 20대 & 22 & 11.4 \\
\hline & 30대 & 117 & 60.9 \\
\hline & 40대 & 53 & 27.7 \\
\hline \multirow{2}{*}{$\begin{array}{l}\text { 부모 } \\
\text { 학력 }\end{array}$} & 고등학교 & 88 & 45.8 \\
\hline & 대학교 & 104 & 54.2 \\
\hline \multirow{5}{*}{$\begin{array}{c}\text { 가족 } \\
\text { 월평균 소득 }\end{array}$} & 200만원미만 & 10 & 5.2 \\
\hline & 200만원 300만원 미만 & 39 & 20.3 \\
\hline & 300만원 400만원 미만 & 66 & 34.3 \\
\hline & 400만원 500만원 미만 & 50 & 26.1 \\
\hline & 500만원 이상 & 27 & 14.1 \\
\hline \multirow{2}{*}{$\begin{array}{l}\text { 아동 } \\
\text { 성별 }\end{array}$} & 여자 & 47 & 24.5 \\
\hline & 남자 & 145 & 75.5 \\
\hline \multirow{4}{*}{$\begin{array}{l}\text { 아동 } \\
\text { 연령 }\end{array}$} & 0 3세 & 48 & 25 \\
\hline & 4 6세 & 48 & 25 \\
\hline & 7 9세 & 48 & 25 \\
\hline & 10 12세 & 48 & 25 \\
\hline \multirow{4}{*}{$\begin{array}{c}\text { 현재 받고 있는 } \\
\text { 치료지원 }\end{array}$} & 장애아동재활치료서비스 & 158 & 82.3 \\
\hline & 문제행동조기개입서비스 & 10 & 5.2 \\
\hline & 유치원/학교 지원 & 10 & 5.2 \\
\hline & 없다 & 14 & 7.3 \\
\hline \multirow{5}{*}{$\begin{array}{l}\text { 치료실을 } \\
\text { 오가는 } \\
\text { 교통수단 }\end{array}$} & 도보 & 49 & 25.5 \\
\hline & 버스 & 59 & 30.7 \\
\hline & 전철 & 9 & 4.7 \\
\hline & 자가용 & 66 & 34.4 \\
\hline & 택시 & 9 & 4.7 \\
\hline \multirow{4}{*}{$\begin{array}{c}\text { 치료실까지 } \\
\text { 소요 시간 }\end{array}$} & 10분 20분 & 62 & 32.3 \\
\hline & 30분 40분 & 111 & 57.8 \\
\hline & 50 분 1시간 & 17 & 8.9 \\
\hline & 1시간 이상 & 2 & 1 \\
\hline
\end{tabular}

\section{2. 연구절차}

\section{1 본조사 설문지에 포함될 선택속성 요인 선정을 위 한 예비조사 절차}

연구자들이 기존의 관련 연구들과 전공 이론지식을 적용하여 장애아 부모가 언어치료실을 선택할 때 중요 하게 고려할 만한 속성들을 선정하고, 선택한 속성들의 타당도를 검증하기 위하여 언어치료학 석사이상 학위 와 한국언어장애전문가협회(현, 한국언어재활사협회) 의 1 급 언어치료사 자격증을 소지하고, 임상경험이 3 년 이상인 언어치료사 4 명에게 이메일로 발송하여 속성들 의 적절성을 검증받았다. 이러한 과정을 통해 선정된 요인들로 예비조사용 개방형 설문지를 제작하고, 예비 조사를 실시하였다.

그 결과를 분석하여 부모들의 선택 빈도가 높은 15 개 의 속성들(언어치료사의 친절성 및 신뢰성, 학력 및 전 공, 아동과의 유대관계 형성능력, 경력 및 자격증 급수, 
언어치료사에 대한 주위 평가; 언어치료 프로그램에 대 한 주위 평판, 언어치료 비용, 치료횟수 선택 가능여부, 부모상담, 관련 재활프로그램 다양성; 치료실과의 거 리·교통·주차, 교재교구, 기관의 공간적 크기 및 인테리 어, 대기실 및 편의시설, 시설의 청결상태 및 안전성)을 1 차 본 조사의 개방형 설문지에 포함시켰다.

\section{2 계층분석용 속성들의 선정을 위한 1 차 본조사(개 방형 설문지) 절차}

장애아 부모들이 언어치료실을 선택할 때 중요하게 고려하는 속성들 간의 우선순위를 분석하기 위한 계층 분석용 설문지 문항을 최종 선정하기 위하여, 예비조사 결과 선정된 선택속성 15 개를 나열한 개방형 설문지를 작성하고, 부모가 언어치료실을 선택할 때 중요하다고 생각하는 항목에 모두 체크하도록 하였다. 그 결과, 총 60 명의 대상자들이 15 개의 항목들에 중복 체크한 빈도 는 396개였다. 항목별로 체크된 빈도를 분석한 결과, 제 시한 15 개의 선택속성 중에서 '시설의 청결상태 및 안 전성'과 '언어치료사의 능력에 대한 주위 평가'가 전 연 령대에서 가장 적게 나타났으며, 또한 다른 하위속성과 개념이 유사하다고 판단되어 제외하였다.

\section{3 계층분석용 설문지를 사용한 2 차 본조사 절차}

속성들의 우선순위 분석에 필요한 계층분석용 설문 지 작성을 위한 절차는 다음과 같았다. 첫째, 예비조사 및 1 차 본조사 결과 선정된 총 13 개의 선택속성들을 3 개의 상위속성으로 범주화하였다. 계층분석용 설문지 에 포함된 상위속성과 그 하위속성들은 '치료사 속성' 4 개(친절성 및 신뢰성, 학력 및 전공, 유대관계 형성능력, 경력 및 자격증 급수), ‘프로그램 속성' 5 개(프로그램에 대한 주위 평판, 언어치료 비용, 치료횟수 선택 가능여 부, 부모상담, 관련 재활프로그램 다양성), '물리적 속성' 4개(거리·교통·주차, 교재교구, 기관의 공간적 크기 및 인테리어, 대기실 및 편의시설)였다.

둘째, 계층분석법(Analytic Hierarchy Process; 이하 $\mathrm{AHP})$ 을 사용하여 선택속성들 간의 상대적인 우선순위 를 결정하기 위하여, 선택된 속성들을 다단계로 계층구 조화하고, 계층구조를 이루고 있는 각 선택속성들을
Satty[27]가 제시한 1 9점 척도로 1:1 쌍대비교 형태로 구성하였다. 쌍대비교는 상위속성들 간 그리고 상위속 성별 하위속성들 간의 비교로 구성하였다[표 3].

\section{표 3. 속성들 간 쌍대비교의 예}

\begin{tabular}{|c|c|c|c|c|c|c|c|c|c|c|c|c|c|c|}
\hline 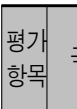 & 극히 & $\begin{array}{r}\text { 물 } \\
- \text {-몬 } \\
\text { 줄 }\end{array}$ & $\begin{array}{l}\text { 믄리적 걶이 } \\
\text { 중요 }\end{array}$ & $\begin{array}{l}\mid \text { 속성 } \\
<-- \text { 조 }\end{array}$ & $\begin{array}{l}\text { 이 } \\
\text { 좀 더 }\end{array}$ & & & - & & $\begin{array}{l}\text { 료사 } \\
\text { 많이 } \\
\text { 중요 }\end{array}$ & & & & \\
\hline $\begin{array}{l}\text { 물리 } \\
\text { 적 (9) } \\
\text { 속성 }\end{array}$ & 9) 8 & (6) & (5) (5) & (4) 3 & 3 (3) & 1 & & & (4) & 5) 6 & & & & $\begin{array}{r}\text { 치료 } \\
\text { 사 } \\
\text { 속성 }\end{array}$ \\
\hline
\end{tabular}

\section{3. 연구일정}

2012년 1월 1일부터 1월 17일까지 선행연구 문헌분석 과 현장전문가 회의를 통하여 중요 요인을 분석하였고, 1월 18일부터 1월 25일까지 예비조사를 위한 개방형 설 문지를 제작하였다. 1 월 26일부터 2월 12 일까지 예비조 사를 실시하였다. 2 월 13 일부터 2월 29일까지 예비조사 결과를 분석하고, 3 월 1일부터 3월 15일까지 예비조사 결과를 바탕으로 본 조사를 위한 개방형 설문지를 제작 하였다.

3 월 16 일부터 3 월 30 일까지는 연령집단별 15 명씩 총 60 명 대상으로 개방형 설문 조사를 실시하고, 그 결과 를 분석하였다. 3 월 31 일부터 4월 16 일까지 개방형 설 문 결과를 참조하여 계층분석용 설문지의 주요 속성 선 정 및 범주화 작업을 실시하였다. 4월 17일부터 4월 25 일까지 계층구조화 및 쌍대비교 형식의 설문지를 제작 하여, 4월 26일부터 5월 10일까지 연령집단별 48명씩 총 192 명을 대상으로 계층분석용 설문 조사를 실시하 였고, 5월 11일부터 5월 15일까지 AHP 분석을 하였다 [그림 1].

\section{4. 설문지 자료 배포 및 회수}

예비조사 및 1 2차 본조사의 자료수집은 모두 연구 자와 설문지 조사에 대한 교육을 받은 연구보조인들이 직접 기관을 방문하여 부모에게 자료수집의 목적과 작 성방법을 설명한 후 응답을 마칠 때까지 기다렸다가 현 장에서 수거하는 방식을 채택하였다. 따라서 자료의 회 수율을 $100 \%$ 였다. 


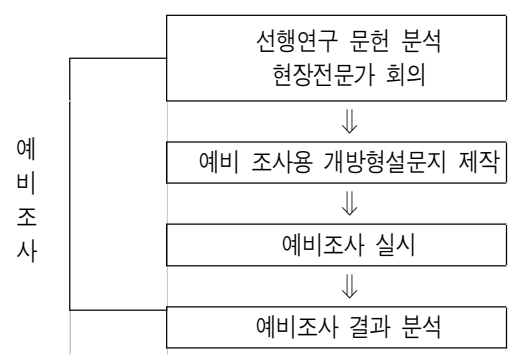

$\Downarrow$

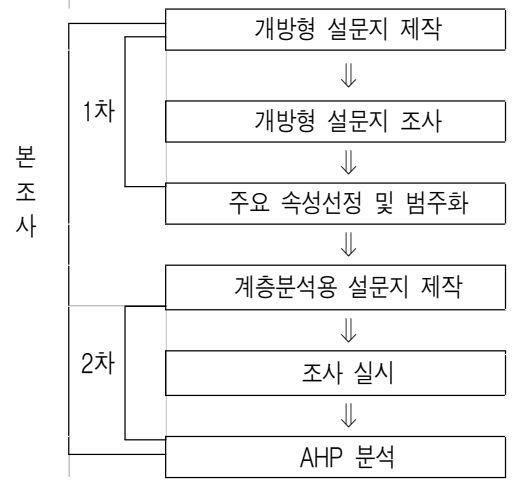

그림 1. 연구절차 도식

\section{5. 통계분석}

$\mathrm{AHP}$ 는 통계방법을 사용한 의사결정방법 중의 하나 로 의사결정의 목표나 평가기준이 다수일 때 대안들을 몇 개의 계층구조로 나누어서 분석 한 후에 상대적인 우선순위를 결정하여 최종적인 의사결정에 이르는 방 법이다. 본 연구의 계층분석용 설문지에 속성별로 1 9 점 척도로 $1: 1$ 쌍대비교한 것에 대한 부모들의 반응을 점수화한 뒤, Microsoft Office Excel(2007)로 기하평균 값(GEOMEAN)을 산출하였으며, 산출된 기하평균값을 바탕으로 재분류된 자료는 $\mathrm{AHP}$ 전용 솔루션인 Expert Choice 2000을 사용하여 우선순위를 분석하였다.

$\mathrm{AHP}$ 를 사용한 우선순위 분석은 우선 상위속성들간 의 우선순위를 분석하고, 그 우선순위에 따라 해당 하 위속성들에 가산 점수가 부여되어, 하위속성간의 상대 적 우선순위를 분석하였다. 속성별 선택률은 상대 비교 한 속성들에 대한 총 반응율을 $100 \%$ 로 할 때 해당 속성 이 차지하는 상대적인 반응비율로 나타냈다.

부모 응답의 일관성(Consistency) 검증을 위하여 일
관성지수(Consistency Index: $\mathrm{CI}$ )를 바탕으로 설문에 대한 응답의 신뢰성을 측정하였다. 이는 부모 집단의 응답이 얼마나 일관성 있게 나타났는가에 대한 신뢰도 측면을 일관성 비율(Consistency Ratio: 이하 $\mathrm{CR}$ )로 검 증하는 방법으로, $\mathrm{CR}$ 값이 0.1 이내 일 경우 합리적 일 관성을 지닌 것으로 판단하고, 0.2 이내 일 경우 수용할 수 있는 수준, 그리고 그 이상이면 일관성이 부족한 수 준으로 판단하였다.

본 연구에서 연령집단을 0 3세, 4 6세, 7 9세, 1 0 12세로 구분하여 분석한 결과, 응답의 CR 값이 0 3 세와 4 6세에서 1.0 이상으로 나타나, 응답의 신뢰성이 확립되지 않았기 때문에 집단별 분석을 0 6세의 학령 전기 아동의 부모집단과 7 12세의 학령기 아동의 부 모집단으로만 나누어 그 결과를 분석하였다. 0 6세 아 동의 부모집단의 $\mathrm{CR}$ 은 0.01 이었으며, 7 12세 아동의 부모집단은 0.03 이었다.

\section{III. 연구결과}

\section{1. 전체 대상자의 속성별 우선순위 분석결과}

\section{1 상하위 속성별 우선순위 분석결과}

본 연구에 포함된 전체 장애아 부모가 언어치료실을 선택할 때 가장 중요하게 생각하는 상위속성은 '치료사 속성'으로 나타났으며, 그 다음이 ‘프로그램 속성'그리 고 '물리적 속성'순으로 나타났다.

상위속성 별 하위속성 우선순위는 '치료사 속성'의 경 우, '학력 및 전공', ‘유대관계 형성능력', '경력 및 자격증 급수'순위로 나타났으며, 세 속성의 선택률은 $29.5 \%$ $26.6 \%$ 사이였다.'친절성 및 신뢰성’은 가장 낮은 순위를 나타냈으며, 선택률도 $16.5 \%$ 로 다른 3 개의 속성과 차이 를 보였다. '프로그램 속성'에서는 '부모상담', '언어치료 비용', '프로그램에 대한 주위 평판'의 순위로 나타났으 며, 반응비율은 $23.5 \%$ 21.2\% 사이로 큰 차이는 없었다. 그 다음으로'치료횟수 선택 가능여부'와 '관련 재활프로 그램 다양성'순이었으며, 다른 3개의 하위속성 비해 $17.7 \%$ 15.3\%로 상대적으로 낮은 선택률 보였다.

‘물리적 속성'에서는 ‘교재교구'가 가장 높은 순위를 
차지했으며, 선택률도 $39.4 \%$ 로 다른 요인들과 상당한 차이를 보였다. 그 다음 순위인 '거리·교통·주차'도 선택 률이 $28.3 \%$ 로 다음 순위 속성인 '대기실 및 편의시 설'(17.5\%)과 '기관의 공간적 크기 및 인테리어'(14.7\%) 와 큰 차이를 나타냈다[표 4].

표 4. 장애아 부모의 언어치료실 상위 및 하위속성별 우선순위

\begin{tabular}{|c|c|c|c|c|}
\hline $\begin{array}{l}\text { 상위 } \\
\text { 속성 }\end{array}$ & $\begin{array}{l}\text { 우선순위 } \\
\text { (선택률) }\end{array}$ & 하위속성 & $\begin{array}{l}\text { 우선순위 } \\
\text { (선택률) }\end{array}$ & $\mathrm{CR}^{\star}$ \\
\hline \multirow{4}{*}{$\begin{array}{l}\text { 치료사 } \\
\text { 속성 }\end{array}$} & \multirow{4}{*}{$1(58)$} & 학력 및 전공 & $1(29.5)$ & \multirow{4}{*}{0.02} \\
\hline & & 유대관계 형성능력 & $2(27.4)$ & \\
\hline & & 경력 및 자격증급수 & $3(26.6)$ & \\
\hline & & 친절성 및 신뢰성 & $4(16.5)$ & \\
\hline \multirow{5}{*}{$\begin{array}{l}\text { 프로 } \\
\text { 그램 } \\
\text { 속성 }\end{array}$} & \multirow{5}{*}{ 2(23.8) } & 부모상담 & $1(23.5)$ & \multirow{5}{*}{0.00} \\
\hline & & 언어치료 비용 & $2(22.3)$ & \\
\hline & & 프로그램에 대한 주위평판 & $3(21.2)$ & \\
\hline & & 치료횟수 선택 가능여부 & $4(17.7)$ & \\
\hline & & 관련 재활프로그램 다양성 & $5(15.3)$ & \\
\hline \multirow{4}{*}{$\begin{array}{l}\text { 물리적 } \\
\text { 속성 }\end{array}$} & \multirow{4}{*}{$3(18.2)$} & 교재교구 & 1 (39.4) & \multirow{4}{*}{0.01} \\
\hline & & 거리 · 교통 · 주차 & $2(28.3)$ & \\
\hline & & 대기실 및 편의시설 & $3(17.5)$ & \\
\hline & & $\begin{array}{c}\text { 기관의 공간적 크기 } \\
\text { 및 인테리어 }\end{array}$ & $4(14.7)$ & \\
\hline
\end{tabular}

${ }^{*} \mathrm{CR}$ (일관성 비율) $<0.1$

\section{2 전체 선택속성들 간의 우선순위 분석결과}

전체 선택속성 문항들에 대한 연구대상자들의 우선 순위 및 선택률을 분석한 결과, 치료사의 '학력 및 전공' 과 '유대관계 형성능력', 그리고 '경력 및 자격증급수'순 으로 나타났으며, 선택률도 $16.9 \%$ 15.2\%로 높은 비율 을 차지하였다. 그 다음으로 '친절성 및 신뢰성'이 약 $10 \%$ 가까운 선택률을 보였다. 그 외에‘부모상담', '언어 치료 비용', '프로그램에 대한 주위 평판', '교재교구', ‘치 료횟수 선택 가능여부', '관련 재활프로그램 다양성', '거 리·교통·주차,'대기실 및 편의시설'그리고 '기관의 공간 적 크기 및 인테리어'순으로 약 7\% 2\%의 선택률을 나 타냈다[표 5].

\section{2. 연령집단별 선택속성 우선순위 분석결과}

\section{1 상위속성 우선순위 분석결과}

연령집단별 상위속성들의 우선순위 분석결과, $0 \sim 6$ 세의 학령전기 아동의 부모집단과 7 12세 학령기 아 동의 부모 집단 모두 ‘치료사 속성’이 가장 높은 우선순 위로 나타났으며, 그 다음으로'프로그램 속성'과 '물리
적 속성' 순을 나타냈다.

\section{표 5. 전체 선택속성의 우선순위}

\begin{tabular}{|c|c|c|c|}
\hline $\begin{array}{l}\text { 우선 } \\
\text { 순위 }\end{array}$ & 세부 선택속성 & $\begin{array}{c}\text { 선택률 } \\
(\%)\end{array}$ & $\mathrm{CR}^{\star}$ \\
\hline 1 & 학력 및 전공 & 16.9 & \multirow{13}{*}{.00} \\
\hline 2 & 유대관계 형성능력 & 15.7 & \\
\hline 3 & 경력 및 자격증급수 & 15.2 & \\
\hline 4 & 친절성 및 신뢰성 & 9.5 & \\
\hline 5 & 부모상담 & 6.9 & \\
\hline 6 & 언어치료 비용 & 6.5 & \\
\hline 7 & 프로그램에 대한 주위 평판 & 6.2 & \\
\hline 8 & 교재교구 & 5.3 & \\
\hline 9 & 치료횟수 선택 가능여부 & 5.2 & \\
\hline 10 & 관련 재활프로그램 다양성 & 4.5 & \\
\hline 11 & 거리·교통·주차 & 3.8 & \\
\hline 12 & 대기실 및 편의시설 & 2.3 & \\
\hline 13 & 기관의 공간적 크기 및 인테리어 & 2 & \\
\hline
\end{tabular}

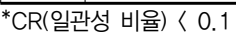

'치료사 속성'의 선택률이 집단별로 각각 $60.8 \%$ 와 $54.5 \%$ 로 다른 상위속성들에 비해 크게 높은 비율을 나 타냈으며, 0 6세 집단은 '프로그램 속성'이 25.7\%로 '물리적 속성'의 $13.5 \%$ 와 상당한 차이를 나타냈으나, 7 12세 집단에서는 두 상위속성의 선택률이 각각 $24 \%$ 와 $21.4 \%$ 로 유사하였다[표 6].

\section{표 6. 연령집단별 언어치료실 상위속성 우선순위}

\begin{tabular}{|c|c|c|c|c|}
\hline 상위속성 & $\begin{array}{c}\text { 0 6세 } \\
\text { 우선순위 } \\
\text { (선택률\%) }\end{array}$ & $\mathrm{CR}$ & $\begin{array}{c}\text { 7 12세 } \\
\text { 우선순위 } \\
\text { (선택률\%) }\end{array}$ & $\mathrm{CR}^{*}$ \\
\hline 치료사 속성 & $1(60.8)$ & \multirow{3}{*}{.02} & 1(54.4) & \multirow{3}{*}{.04} \\
\hline 프로그램 속성 & $2(25.7)$ & & $2(24.0)$ & \\
\hline 물리적 속성 & $3(13.5)$ & & $3(21.6)$ & \\
\hline
\end{tabular}

${ }^{*} \mathrm{CR}($ 일관성 비율 $)<0.1$

\section{2 상위속성 범주별 하위속성 우선순위 분석결과}

연령집단별로 상위속성 범주별로 하위속성들의 우선 순위를 분석한 결과, 0 6세의 학령전기 아동의 부모 집단은치료사 속성'범주의 하위속성들 중에선 '경력 및 자격증급수(33.6\%)'가 가장 높았으며, '유대관계 형성능 력(28\%)', '학력 및 전공(21.4\%)' 그리고 '친절성 및 신 뢰성(17\%)' 순으로 나타났다. 반면에 7 12세의 학령기 아동의 부모집단은 '학력 및 전공(38.8\%)'이 가장 높았 으며, '유대관계 형성능력25.7\%)', '경력 및 자격증급수 (20.1\%)' 그리고 '친절성 및 신뢰성(15.4\%)'순으로 나타 
났다.

'프로그램 속성'의 하위속성들의 경우, 0 6세 아동의 부모집단은 '부모상담(36.5\%)'이 다른 하위속성들과 큰 차이가 나는 높은 선택률을 보이며 가장 높은 우선순위 를 나타냈으며, '프로그램에 대한 주위 평판(21.7\%)', '관련 재활프로그램 다양성(17.7\%)', '언어치료 비용 (13.4\%)'그리고'치료횟수 선택 가능 여부(10.6\%)'순으 로 나타났다. 반면, $7 \sim 12$ 세의 아동의 부모집단은 '언어 치료비용(31.8\%)'이 가장 높은 우선순위로 나타났으며, '치료횟수 선택 가능(24.6\%)', '프로그램에 대한 주위평 판(18.7\%)', '부모상담(13.4\%)', 그리고'관련 재활프로그 램의 다양성(11.5)'순으로 나타나 0 6세 아동의 부모집 단과 상당한 차이를 보였다.

‘물리적 속성'의 하위 속성들 분석결과, 0 6세 아동 의 부모집단에서는 '교재교구'가 $46.5 \%$ 라는 압도적인 선택률로 가장 높은 선택속성으로 나타났으며, 그 다음 으로 '대기실 및 편의시설(21.9\%)', 거리, 교통, 주차 (17.8\%)' 그리고 '공간적 크기 및 인테리어(13.8\%)'의 순으로 나타났다. 반면에 7 12세 아동의 부모집단에서 는 '거리, 교통, 주차(41.5\%)'와 '교재교구(30.9\%)'가 높 은 비율로 1,2 순위를 나타냈으며, '공간적 크기 및 인 테리어(14.7\%)', 그리고'대기실 및 편의시설(13\%)'순으 로 나타나, 아동의 연령집단별 부모들의 물리적 하위 속성에 대한 우선순위가 상당한 차이가 있는 것으로 나 타났다[표 7].

\section{표 7. 연령집단별 상위속성 범주별 하위속성의 우선순위}

\begin{tabular}{|c|c|c|c|c|c|}
\hline & 하위속성 & $\begin{array}{c}\text { 0 6세 } \\
\text { 우선순위 } \\
(\%)\end{array}$ & $\mathrm{CR}$ & $\begin{array}{c}\text { 7 12세 } \\
\text { 우선순위 } \\
\text { (\%) }\end{array}$ & $\mathrm{CR}$ \\
\hline \multirow{4}{*}{$\begin{array}{l}\text { 치료 } \\
\text { 사 } \\
\text { 속성 }\end{array}$} & 경력 및 자격증급수 & $1(33.6)$ & \multirow{4}{*}{.01} & $3(20.1)$ & \multirow{4}{*}{.03} \\
\hline & 유대관계 형성능력 & $2(28.0)$ & & $2(25.7)$ & \\
\hline & 학력 및 전공 & $3(21.4)$ & & $1(38.8)$ & \\
\hline & 친절성 및 신뢰성 & $4(17.0)$ & & $4(15.4)$ & \\
\hline \multirow{5}{*}{$\begin{array}{l}\text { 프로 } \\
\text { 그램 } \\
\text { 속성 }\end{array}$} & 부모상담 & $1(36.5)$ & \multirow{5}{*}{.01} & $4(13.4)$ & \multirow{5}{*}{.01} \\
\hline & 프로그램에 대한 주위 평판 & $2(21.7)$ & & $3(18.7)$ & \\
\hline & 관련 재활프로그램 다양성 & $3(17.7)$ & & $5(11.5)$ & \\
\hline & 언어치료 비용 & $4(13.4)$ & & $1(31.8)$ & \\
\hline & 치료횟수 선택 가능여부 & $5(10.6)$ & & $2(24.6)$ & \\
\hline \multirow{4}{*}{$\begin{array}{l}\text { 물리 } \\
\text { 적 } \\
\text { 속성 }\end{array}$} & 교재교구 & $1(46.5)$ & \multirow{4}{*}{.01} & $2(30.9)$ & \multirow{4}{*}{.01} \\
\hline & 대기실 및 편의시설 & $2(21.9)$ & & $4(13.0)$ & \\
\hline & 거리·교통·주차 & $3(17.8)$ & & $1(41.5)$ & \\
\hline & $\begin{array}{c}\text { 기관의 공간적 크기 및 } \\
\text { 인테리어 }\end{array}$ & $4(13.8)$ & & $3(14.7)$ & \\
\hline
\end{tabular}

${ }^{*} \mathrm{CR}$ (일관성 비율) < 0.1

\section{3 연령집단별 전체 속성 우선순위 분석결과}

상위속성 범주별로 구별하지 않고 전체 선택속성들 간의 우선순위를 분석한 결과, 0 - 6세 아동의 부모집단 에서는 역시 상위속성들 중에서 가장 중요하게 선택된 '치료사 속성'의 하위속성들인 '경력 및 자격증급수 (21.7\%), ‘유대관계 형성능력(18.0\%)', '학력 및 전공 (13.8\%)' '친절성 및 신뢰성(10.9\%)'이 1 4순위로 나타 났으며, '프로그램 속성' 중 '부모상담(9.2\%)'이 5순위로 나타났다. 7 12세 아동의 부모집단에서도 역시 가장 중요하게 선택되었던 상위속성인 '치료사 속성'의 하위 속성들인 '학력 및 전공(20.5)', ‘유대관계 형성능력 (13.5)' 그리고 '경력 및 자격증급수(10.6)'가 1 3순위로 나타났으나, 0 6세 아동의 집단에는 최하위 수준에 머 무른 치료실과의 '거리 - 교통 - 주차(9.0\%)'가 4순위를 보였다. 5순위는 치료사의 '친절성 및 신뢰성(8.1\%)'과 '언어치료 비용(8.1\%)'이었다. '부모상담'은 학령기인 7 12세 아동의 부모집단에서는 9순위(3.4\%)로 나타나 0 6세 아동의 부모집단에 비해 상대적으로 낮은 우선 순위를 보였다[표 8].

\section{표 8. 전체 연령집단별 선택속성의 우선순위}

\begin{tabular}{|c|c|c|c|c|}
\hline 세부 선택속성 & $\begin{array}{c}\text { 0 6세 } \\
\text { 우선순위 } \\
(\%)\end{array}$ & $\mathrm{CR}$ & $\begin{array}{c}7 \sim 12 \text { 세 } \\
\text { 우선순위 } \\
(\%)\end{array}$ & CR \\
\hline 경력 및 자격증급수 & $1(21.7)$ & \multirow{13}{*}{.01} & $3(10.6)$ & \multirow{13}{*}{.03} \\
\hline 유대관계 형성능력 & $2(18.0)$ & & $2(13.5)$ & \\
\hline 학력 및 전공 & $3(13.8)$ & & $1(20.5)$ & \\
\hline 친절성 및 신뢰성 & $4(10.9)$ & & $5(8.1)$ & \\
\hline 부모상담 & $5(9.2)$ & & $9(3.4)$ & \\
\hline 프로그램에 대한 주위평판 & $6(5.5)$ & & $8(4.8)$ & \\
\hline 교재교구 & $7(4.8)$ & & $6(6.7)$ & \\
\hline 관련 재활프로그램 다양성 & $8(4.5)$ & & $11(2.9)$ & \\
\hline 언어치료 비용 & $9(3.4)$ & & $5(8.1)$ & \\
\hline 치료횟수 선택 가능여부 & $10(2.7)$ & & $7(6.3)$ & \\
\hline 대기실 및 편의시설 & $11(2.3)$ & & $12(2.8)$ & \\
\hline 거리·교통 · 주차 & $12(1.9)$ & & $4(9.0)$ & \\
\hline 공간적 크기 및 인테리어 & $13(1.4)$ & & $10(3.2)$ & \\
\hline
\end{tabular}

${ }^{*} \mathrm{CR}$ (일관성 비율) $<0.1$

\section{IV. 논 의}

장애아 부모의 언어치료 관련 선택속성들에 대한 우 선순위의 분석과 대상자 연령에 따른 요구분석은 언어 
치료기관이 보다 수준 높은 언어치료를 계획하고 제공 하는데 중요한 정보를 제공하며, 따라서 임상현장에서 언어치료의 질적인 향상을 위해 필수적이다. 그러므로 본 연구는 장애아 부모가 언어치료실을 선택할 때 중요 하게 고려하는 선택속성들을 파악하고, 선택된 속성들 간의 우선순위를 분석하였으며, 아동의 연령집단별로 부모집단을 나누어 집단별 선택속성들의 우선순위를 비교분석하였다.

본 연구의 결과 및 그에 대한 논의는 다음과 같다. 첫째, 0 12세 장애아 부모들이 언어치료실을 선택할 때 중요하게 생각하는 요인들은 치료사와 관련된 속성 들(치료사 속성)인 치료사의 친절성 및 신뢰성, 학력 및 전공, 유대관계 형성능력, 경력 및 자격증 급수 그리고 언어치료실의 프로그램과 관련된 속성들(프로그램 속 성)인 프로그램에 대한 주위 평판, 언어치료 비용, 치료 횟수 선택 가능여부, 부모상담, 관련 재활프로그램 다양 성 그리고 기관의 물리적 특성과 관련된 속성들(물리적 속성)인 거리·교통·주차, 교재교구, 기관의 공간적 크기 및 인테리어, 대기실 및 편의시설이었다.

둘째, 전체 부모들을 대상으로 언어치료실을 선택할 때 가장 중요하게 고려하는 요인들의 상위속성을 분석 한 결과, ‘치료사 속성'이 ‘프로그램 속성'이나 '물리적 속성'과 큰 차이를 보이며 가장 높은 순위를 나타냈다. 하위속성들 간의 우선순위 분석결과 역시 '치료사 속성' 의 하위속성들인'학력 및 전공’이 가장 높았고, 그 뒤로 ‘유대관계 형성능력', ‘경력 및 자격증급수' ‘친절성 및 신뢰성' 순으로, 총 13 개의 속성들 중에서 부모들이 언 어치료실을 선택할 때 가장 주요하게 생각하는 1 4순 위가 치료사와 관련된 속성들인 것으로 나타났다. 서연 태 등의 지적장애인 부모의 신체활동 선택속성 분석결 과에서도, 부모들은 교사와 관련된 속성인'교사 속성'을 가장 중요하게 생각하다고 선택하였으며[3], 그 하위속 성으로 '교사의 전문성', '교사 평판조회', ‘교사의 친절 성'이 높은 선택률을 나타냈다. 변애심도 장애아 부모가 언어치료실을 선택할 때 '교사의 자격이나 전공'을 가장 중요하게 고려한다고 보고한 바 있다[19]. 이러한 결과 는 부모들이 언어치료실을 선택할 때 언어치료사의 능 력과 전문성을 가장 중요한 기준으로 적용하는 것을 보
여준다. 또한 부모들이 치료사의 학문적인 전문성뿐만 아니라 아동과의 유대형성 능력, 치료사로서의 인성 및 태도와 관련된 속성 또한 가장 우선시하는 요구들 중 하나라는 것을 보여주는 것으로, 치료사 자신뿐만 아니 라 교육 및 임상현장에서 이러한 측면의 함양에 대한 지속적인 노력이 필요함을 보여준다. 언어치료사 자격 증이 국가자격증이 된 현 시점에서 언어치료사의 전문 성 함양을 위한 국가수준의 철저한 자격관리도 중요하 다고 하겠다.

셋째, 아동의 연령을 0 6세의 학령전기와 7 12세의 학령기로 나누어 아동의 연령집단별로 부모들의 언어 치료실 선택속성을 분석한 결과, 상위속성들의 우선순 위는 두 연경집단 모두 전체 부모들의 우선순위와 동일 하게 나타났다. 그러나 속성별 선택률의 경우에 학령전 기 아동의 부모집단에서는 학령기 아동의 부모들에 비 해 '치료사 속성'의 비율이 높았으며, 학령기 아동의 부 모집단은 학령전기 아동의 부모들에 비해 상대적으로 '물리적 속성'에 대한 선택률이 높게 나타났다.

아동의 연령집단별 부모들의 하위속성에 대한 우선 순위를 분석한 결과, '치료사 속성'에서 0 6세의 아동 부모들은 '경력 및 자격증급수, '유대관계 형성능력' 등 의 순으로 나타났고, 7 12세의 아동 부모들은 '학력 및 전공', ‘유대관계 형성능력' 등의 순으로 나타났다. 두 집단 모두에서 '치료사의 유대관계 형성능력'을 중요한 속성으로 생각하고 있지만, 0 6세의 아동 부모들은 치 료사의 학력이나 전공보다는 치료 경험이 어린 아동과 의 유대관계 형성 및 치료에 더 많은 영향을 미치는 요 인으로 판단하고 있으며, 학령기 아동의 부모들에 비하 여 상대적으로 언어치료사의 '자격증 급수'에 더 큰 의 미를 부여하는 것으로 보인다. 반면, 치료 경험이 상대 적으로 많은 7 12세 학령기 아동의 부모들은 단순 치 료 경력 자체보다는 치료사가 언어치료를 전공하고 학 문의 전문성을 갖추었는가를 좀 더 중요한 우선순위로 판단하는 것으로 보인다. 이에 우리나라 연구에서 학력, 경력을 따로 구분지어 만족도를 조사한 연구는 없지만 학력, 경력 모두 전문성으로 본다면, [19][21][28]에서 장애아 부모가 가장 중요하게 고려하는 부분은 바로 '치료사의 전문성'으로 나타났다. 김향희는 언어치료 전 
문가로서 자리매김을 하기 위해서는 반드시 첫째, 대학 교 이상의 전공학과에서 체계적인 교육과 충분한 실습 이 필요하며, 둘째, 자격검정을 통하여 '전문가다움'을 검증받아야 한다고 하였다. 그리도 마지막으로 셋째, 정 기적인 보수교육으로 자신의 지식 및 기술을 계속적으 로 연마해 나가야 한다고 주장한 바 있다[29].

'프로그램 속성'의 하위속성들에서는 다른 속성들에 비해 아동의 연령집단별로 부모들이 중요시 하는 속성 들의 우선순위가 큰 차이를 보였다. 0 6세인 학령전기 아동의 부모들은 '부모상담'과 '프로그램에 대한 주위 평판'을 가장 중요한 우선순위 속성으로 선택한 반면, 7 12세 학령기 아동의 부모들이 가장 중요한 우선순 위 속성으로 선택한 '언어치료 비용'과 '치료횟수 선택 가능 여부'는 프로그램 속성 중 가장 낮은 순위를 보였 다. 학령기 아동의 부모들은'부모상담’에 대한 요구는 학령전기 아동들의 부모들에 비해 상대적으로 매우 낮 았다. 본 연구에 참여한 부모들의 $0 \sim 6$ 세 아동과 7 12 세 아동의 치료받은 기간을 분석한 결과, 0 6세는 평 균 치료기간이 14 개월이었으며, 7 12세 아동은 평균 40개월로 나타나 두 집단 간에 상당한 차이를 나타냈 다. 두 집단 간의 치료기간의 차이를 고려하여 이러한 결과를 해석한다면, 치료를 받기 시작하는 시기이거나 치료기간이 짧은 0 6세의 어린 아동의 부모들은 장애 나 언어치료 등에 대한 구체적인 정보를 제공받을 수 있는 '부모상담'에 대한 요구가 학령기 아동의 부모들에 비해 상대적으로 큰 것으로 볼 수 있다. 특히 어린 연령 의 아동들의 경우에는 언어치료를 진행하는 동안 그들 의 양육자나 가족과의 상담은 필수적이며 아주 중요한 치료과정이다[2]. 많은 연구들에서 장애아동의 부모가 내담자로서의 역할을 잘 수행했을 때 아동의 치료 효과 를 높일 수 있으며, 또한 부모와 치료사 간의 부모상담 은 아동을 치료하는데 중요한 요소이고, 치료 효과를 극대화한다는 것이 공통된 의견이다[30-35]. 그러므로 어린 연령의 아동을 치료할 때 '부모상담'은 부모의 요 구 충족이나 언어치료의 효과 측면에서 반드시 중요하 게 고려해야 할 속성이다.

0 6세 아동의 부모들은 7 12세 아동 부모들에 비해 '프로그램에 대한 주위의 평판'을 치료실 선택의 중요
속성으로 선택한 것도 상대적으로 치료실에 대한 경험 이나 정보가 부족한 것이 원인일 수 있다. 반면 7 12세 아동의 부모들은 0 6세 아동의 부모들이 가장 낮은 순 위로 선택한 '언어치료 비용'과 '치료횟수 선택의 가능 여부’가 치료실을 선택하는 가장 중요한 프로그램 관련 요인으로 선택하였다. 우리나라가 재활치료 지원인 바 우처 사업을 통해 18 세 미만 장애아동에게 치료비지원 을 해주고 있지만[36], 의료보험의 기준제한이 있으며, 장애인등록을 하지 않고는 지원을 받지 못하기 때문에 아직까지는 현실적으로 장애인 치료비 지원이 많이 부 족한 상태로 보고되고 있다[37][38]. 그러므로 7 12세 의 학령기 아동의 부모는 앞서 기술한 바와 같이 학령 전기 아동들에 비해 오랫동안 언어치료를 받아 왔거나 언어치료의 장기적 속성을 인식하고 있는 집단일 가능 성이 높으며, 따라서 상대적으로 치료비용이 중요한 속 성으로 작용할 수 있다. 또한 아동이 학령기라는 특성 을 고려할 때 학교수업이나 기타 교육 시간과 병행할 수 있는 치료시간의 선택 가능성도 학령전기 연령에 비 해서는 부모들이 중요하게 생각하는 요인으로 보인다.

물리적 속성에서 0 6세와 7 12세 아동 부모들은 공 통적으로 '교재교구의 다양성'을 중요한 속성으로 생각 하는 것으로 나타났다. 심미진의 연구에서도 치료실에 대해 교재·교구의 중요성을 강조하였다[21]. 0 6세와 7 12세 아동의 부모들이 특히 차이를 보인 점은'대기 실 및 편의시설'이 0 6세 아동 부모들에서는 2순위로 선택된 반면, 7 12세 아동 부모들에게서는 가장 적게 선택되었으며, 학령기 아동의 부모들이 높은 순위로 선 택한 '거리·교통·주차시설'이 어린연령대에서는 상대적 으로 낮은 선택률을 보였다. 어린 연령의 부모들은 어 린 아동과 함께 시간을 보내야 하는 대기실의 편안함과 안락함이 학령기 아동의 부모들보다는 상대적으로 중 요한 요인으로 작용할 수 있다. 소아과 대기실을 연구 한 양선희[39]와 한명옥[40]은 아동은 주위 환경에 가 장 민감하게 반응하는 시기이며, 편안한 대기실은 아동 의 심리적 안정으로 치료에 도움을 줄 수 있다고 하였 다. 또한 언어치료실과 거주지의 거리나 교통수단 및 주차시설도 치료실을 이용하는 장애아동들의 부모에게 중요한 요인으로 나타났다. 이수정은 재활치료를 이용 
하는 장애아의 부모들이 '치료실로 이동하는 거리의 부 담'과 '교통이용의 불편함'이 높다고 보고하였으며[41], 놀이치료실 이용 부모들을 연구한 정희정도 대부분 이 용자들이 거주지와 가까운 치료실을 선호한다고 보고 하였다[42]. 변애심의 장애아 부모의 언어치료실에 대 한 만족도 연구결과에서도 언어치료실까지 왕복 소요 기간이 1 시간으로 나타나 치료실까지의 시간 손실이 많은 것을 문제점으로 지적하였다[19]. 특히 본 연구에 서 학령기 아동들의 부모집단에서 상대적으로 높은 선 택을 보인 이유 또한 학령기라는 특성을 고려할 때, 어 린 연령들에 비하여 하교시간이 늦고, 따라서 치료를 받을 수 있는 시간이 제한된다는 점을 고려할 때 먼 거 리나 불편한 교통으로 인한 시간적 손실이 치료실을 선 택할 때 장해요인일 수 있다. 학령기 아동의 부모들이 상대적으로 '치료횟수 선택 가능여부'를 언어치료실 선 택의 주요한 속성으로 선택한 점은 이러한 추론을 지지 한다.

\section{V. 결 론}

본 연구는 언어치료실에 대한 장애아 부모의 다양한 요구를 파악하여 좀 더 효과적인 언어치료실을 위한 정 보를 제공하고자 하였다. 이를 위하여 부모들의 언어치 료실 선택속성을 분석한 결과, 부모들은 '치료사 관련' 속성을 가장 중요시 하는 것으로 나타났으며, 구체적 속성들로는 '치료사의 학력과 전공', '유대관계 형성능 력', ‘경력 및 자격증 급수', ‘친절성과 신뢰성' 그리고 '부모상담' 이 높은 우선순위를 나타냈다. 아동의 연령 집단별로 분석한 결과, 학령전기 아동의 부모들은 '치료 사의 경력 및 자격증급수, '부모상담', '교재교구의 다양 성'을 가장 중요시 한 반면, 학령기 아동의 부모들은 '치 료사의 학력 및 전공', '언어치료 비용', '거리 · 교통 - 주 차’를 최우선 순위로 선택하였다. 이러한 결과는 향후 성공적인 언어치료실을 계획하기 위한 기초자료로 활용 될 수 있을 것이다. 특히 전체적인 부모들의 요구뿐만 아니라 연령집단별로 우선적 요구의 차이가 있다는 점 을 인식하고 다양한 소비자의 요구에 맞는 서비스를 제
공함으로써 언어치료의 질적인 향상은 물론 부모들의 만족도를 좀 더 충족시킬 수 있는 방법이 될 수 있다.

본 연구는 서울, 인천, 경기 지역에 거주하는 부모들 을 대상으로 도출해낸 결과이기 때문에 지역적 특성의 추세와 다소 차이가 있을 수 있다는 제한점이 있다.

\section{참 고 문 헌}

[1] 김수진, 윤철수, 유영준, 치료지원 바우처사업 이 용자 실태 및 욕구조사, 한국언어청각임상학회 학 술대회 발표논문집, 2008.

[2] American Speech-Language-Hearing Association. Roles and responsibilities of speech language pathologists, Rockville, 2001.

[3] 서연태, 김춘종, 정기천, "장애인의 신체활동 프 로그램 준비단계 요인의 상대적 중요도와 우선순 위 분석”, 한국특수체육학회지, 제 14 권, 제 4 호, pp.197-208, 2011.

[4] J. Engelhardt, T. H. Brubaker, and V. D. Lutzer, "Older caregivers of adults with mental retardation: Service Utilization," Mental Retardation, Vol.26, No.4, pp.191-195, 1998.

[5] P. Kotler, J. Bowen, and S. R. Schroeder, "Predictors of urgency of out-of-home placement needs," Mental Retardation, Vol.26, No.6, pp.323-328, 1991.

[6] P. Kotler, J. Bowen, and J. C. Makens, Marketing for hospitality and tourism, Upper Saddle River, 1998.

[7] 권기준, 이형룡, “소규모 레스토랑 물리적환경요 인의 상대적중요도와 우선순위 도출: $\mathrm{AHP}$ 분석을 이용하여", 한국호텔외식경영학회지, 제 20 권, 제 2 호, pp.35-51, 2011.

[8] 오연풍, "장애인체육 진흥을 위한 투자 우선순위 설정에 관한 연구”, 한국특수체육학회지, 제 12 권, 제3호, pp.15-24, 2004.

[9] 이상일, 유현숙, “스포츠 프로그램 소비자의 선택 
속성에 관한 연구”, 한국여가 레크리에이션학회 지, 제26권, pp.39-50, 2004.

[10] 김수진, “치료지원 바우처사업 대상아동의 장애 유형과 연령에 따른 재활치료 실태 및 부모욕구 조사", 언어청각장애연구, 제13권, 제4호, pp.169-706, 2008.

[11] 이소현, 유아특수교육, 학지사, 2003.

[12] 이소현, 조윤경, "0-2세 발달지체 영아들을 위한 조기 개입 서비스현황 및 프로그램 운영을 위한 지원 욕구”, 언어치료 청각장애연구, 제 9 권, 제 1 호, 2004.

[13] 김수진, 김정미, 윤미선, 김정연, 도연지, 이수향, 최은아, "특수교육 관련서비스의 복지관 제공실 태 및 장애아 부모욕구 분석을 위한 기초연구”, 언 어청각장애연구, 제10권, 제1호, pp.153-170, 2005.

[14] 김영환, 장애인복지관 운영에 따른 이용자 만족 도에 관한 연구, 대구대학교 사회복지대학원, 석 사학위 논문집, 2009.

[15] 김은선, 발달장애인 서비스 만족도에 관한 연구: 기관 유형에 따른 만족도 비교를 중심으로, 가톨 릭대학교 사회복지대학원, 석사학위논문집, 2001.

[16] 김정완, "자폐 장애 아동 보호자의 언어치료 교 육 서비스 만족도에 대한 실태조사”, 한국콘텐츠 학회논문집지, 제 11 권, 제3호, 2010.

[17] 김지영, 언어장애아 부모의 언어치료 서비스에 대한 인식조사, 대구대학교 교육대학원, 석사학위 논문집, 2006.

[18] 박희숙, 영유아 보육시설의 연구, 전남대학원 유 아교육학과 석사학위 논문집, 2000.

[19] 변애심, 장애아 부모의 언어치료실에 대한 이용 실태, 만족도 그리고 개선방향에 관한 연구: 사설 언어치료실, 장애인 복지관, 병원 언어치료실을 중심으로, 용인대학교 교재활보건과학대학원, 석 사학위 논문집, 2006.

[20] 신귀연, 장애아동 부모의 의료재활 서비스에 관 한 만족도 연구-대전관역기 물리, 작업, 언어치료 를 받는 장애아동의 부모를 대상으로, 대전대학교 행정대학원, 석사학위 논문집, 2001.
[21] 심미진, 대학기관 내에서 제공하는 언어치료 서 비스에 대한 부모 만족도에 관한 연구, 나사렛대 학교 재활복지대학원, 석사학위 논문집, 2011.

[22] 이송민, 정신지체 특수학교 고등부 학생의 전이 계획에 대한 부모의 옥구 조사, 이화여자대학교 대학원, 석사학위 논문집, 1996.

[23] 임소연, 복지관 언어치료 서비스의 운영 실태와 언어치료의 직무 만족도 조사, 나사렛대학교 재활 복지대학원, 석사학위 논문집, 2003.

[24] 조은혜, 언어장애아 부모의 언어치료서비스에 대한 만족도가 재이용 및 권유의사에 미치는 영 향, 명지대학교 사회교육대학원, 석사학위 논문집, 2007.

[25] 조은희, 복지관내 방과후 아동지도에 대한 부모 의 서비스만족도에 관한 연구, 이화여자대학교 사 회복지대학원 석사학위 논문집, 1998.

[26] 최경애, 장애아동 음악치료의 효과성 제고를 위 한 장애아동부모의 만족도 조사, 한세대학교대학 원 석사학위 논문집, 2005.

[27] T. L. Saaty, "A Scaling method for Priorities in hierarchical structures," Journal of Mathematical phyology, Vol.15권, No.3, pp.23-281, 1977.

[28] 전병진, 이지연, "치료교육에 대한 장애아동 부 모의 옥구 조사에 관한 연구”, 대한작업치료학회 지, 제14권, 제1호, pp.71-78, 2006.

[29] 김향희, "국외 언어치료사 및 국내 유관 분야의 자격제도에 대한 고찰", 언어청각장애연구, 제 12 권, 제3호, pp.394-411, 2007.

[30] 기채영, “놀이치료에서의 부모상담의 치료성과 요인 및 과정에 대한 질적 연구”, 놀이치료연구, 제9권, 제2호, pp.41-58, 2006.

[31] 심영숙, 언어치료에서 부모상담에 대한 어머니 와 상담자의 인식연구, 목포대학교 교육대학원, 석사학위 논문집, 2012.

[32] 이혜자, "아동미술치료에서의 부모상담현황 및 부모상담에 대한 치료사와 부모의 인식에 관한 조사 연구”, 한국 예술치료학회, 제8권, 제 2 호, pp.17-38, 2008. 
[33] 최명선, "아동상담에서 부모와 치료자간 치료관 계에 대한 연구”, 아동학회지, 제 26 권, 제 3 호, pp.111-125, 2005.

[34] R. Comas, J. Cecil, and C. Cecil, "Using expert opinion to determine of essentional development needs of school counselor," School Counselor, Vol.34, pp.81-87, 1987.

[35] D. Siskind, Working with Parents: Establishing the essential alliance in child psychotherapy and consultation, Jason Aronson, 1997.

[36] 김동호, 장애아동-가족지원 정책의 방향, 장애아 동 재활치료서비스 사업의 현황 및 향후과제, 국 회도서관, 2008.

[37] 김종해, "정부의 사회복지서비스 이용권(바우처) 도입 계획에 대한 우려”, 복지동향, 제101권, pp.24-27, 2007.

[38] 김진, "바우처 제도의 이해와 현황: 복지와 선택을 중심으로”, 월간재정포럼, 제131권, pp.22-39, 2007.

[39] 양선희, 소아병원의 색체 디자인에 관한 연구: 입구(로비)와 대기실의 공간을 중심으로, 중앙대 학교 예술대학원, 석사학위 논문집, 2012.

[40] 한명옥, 소아과 대기실의 실내공간구성에 관한 연구, 이화여자대학교 산업미술대학원, 석사학위 논문집, 1985.

[41] 이수정, 장애아동 재활치료 바우처 서비스 만족 도의 영향요인에 관한 연구, 삼육대학교 대학원, 석사학위 논문집, 2011.

[42] 정희정, 놀이치료 종결과 관련된 변인의 탐색연 구, 숙명여자대학교 대학원, 석사학위 논문집, 2003.
저 자 소 개

김 선(Sun Kim)

정회원

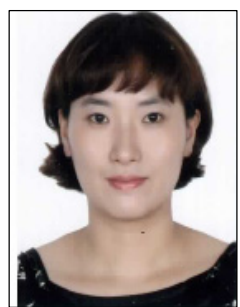

- 2012년 8월 : 나사렛대학교 언어 치료학과(언어치료 석사)

- 2007년 현재 : 인천아동발달 센터 원장

<관심분야> : 언어치료, 부모 상담

\section{홍 경 훈(Gyung-Hun Hong)}

정회원

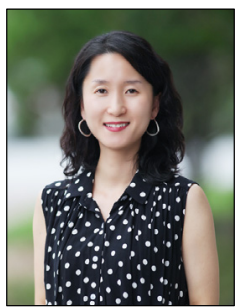

- 1995년 5월 : Boise State University, Special Education (교육학 석사)

- 2005년 2월 : 이화여자대학교 언 어병리학협동과정(언어병리학 박사)

- 2008년 3월 현재 : 나사렛대학교 언어치료학과 교수 <관심분야> : 언어발달, 영유아언어장애, 부모상담 